\title{
A study of the effects of intradermal administration of recombinant gamma interferon in lepromatous leprosy patients
}

\author{
N M SAMUEL,* J M GRANGE,* S SAMUEL,* \\ S LUCAS, $†$ O M OWILLI, $† S$ ADALLA, $\S$ \\ I M LEIGH $\uparrow$ \& C NAVARRETTE \\ * Department of Microbiology, Cardiothoracic Institute, Fulham \\ Road, London; $\dagger W o l f s o n$ Tropical Pathology Unit, School of \\ Hygiene \& Tropical Medicine, London WC1; $\ddagger$ Kenyatta National \\ Hospital, Nairobi, Kenya; § Alupe Leprosy Hospital and Training \\ Unit, Busia, Kenya; I Department of Experimental Dermatology \\ and Immunology, The London Hospital Medical College
}

\section{Accepted for publication 24 March 1987}

\begin{abstract}
Summary Twenty-six leprosy patients ( 23 lepromatous, 2 borderline tuberculoid and 1 with indeterminate disease) were treated with recombinant gamma interferon ( $\mathrm{rIFN}-\gamma)$ intralesionally. Patients were divided into 3 groups. Group A received $10 \mu \mathrm{g}$ dose of rIFN- $\gamma$ for 3 consecutive days; Group B $20 \mu \mathrm{g}$ for 3 days and Group $\mathrm{C} 20 \mu \mathrm{g}$ for 5 days. Twenty-three pairs of skin biopsies and 25 pairs of radial cutaneous nerves were obtained prior to, and 2 days following, the last injections of rIFN- $\gamma$. Leprosin A skin tests were negative before and after rIFN- $\gamma$. Injections of rIFN- $\gamma$ induced indurated swelling characteristic of delayed type hypersensitivity in all patients. Histologically, rIFN- $\gamma$ caused localized oedema, influx of mononuclear cells and eosinophils; epithelioid cell transformation and rapid reduction in the numbers of acid-fast bacilli in the majority of the patients. Immunocytochemical analysis revealed an increase in pan $T$ cells, with equal numbers of $T_{8}$ and $T_{4}$ phenotypes, and increased expression of HLA-class II antigens of macrophages, epithelial cells and keratinocytes. These immunological changes indicate a shift in the immune spectrum of lepromatous leprosy. These results suggest that rIFN- $\gamma$ may be used in lepromatous leprosy as an adjunct to chemotherapy.
\end{abstract}

\section{Introduction}

Leprosy exhibits a wide range of cell-mediated immune responses resulting in a spectrum of disease ranging from paucibacillary tuberculoid to multibacillary lepromatous forms.' Patients with lepromatous ( $(\mathrm{L})$ leprosy have defective cell-mediated immune responses to the causative organism which permit the extensive replications of Mycobacterium leprae in the dermal macrophages. ${ }^{2}$ The LL patients are anergic to skin testing reagents derived from $M$. leprae and their lesions are deprived 
of helper T cells, a source of gamma interferon (IFN- $\gamma$ ) ${ }^{3}$ The peripheral blood lymphocytes of patients with LL fail to produce IFN- $\gamma$ when exposed to $M$. leprae. . $^{4.5}$

Gamma interferon is a glycoprotein with anti-viral, immunomodulatory, and anti-proliferative properties. It is secreted by lymphocytes and profoundly affects the mononuclear phagocytes. ${ }^{6}$ The experimental data available from both mice and man suggest that IFN- $\gamma$ enhances the capacity of mononuclear phagocytes to release hydrogen peroxide and to kill protozoal parasites and bacterial pathogens. $^{7-9}$

If IFN- $\gamma$ is the main lymphokine responsible for the activation of macrophages for mycobactericidal activity then exogenous administration in lepromatous leprosy patients may perhaps induce an effective immune reaction and thereby decrease the bacterial load from lesions.

While planning these studies, a report ${ }^{10}$ showed that small amounts of recombinant gamma interferon (up to $10 \mu \mathrm{g}$ ) injected into lepromatous leprosy patients had no adverse effects. That report also showed that injection of $1-10 \mu \mathrm{g}$ of INF- $\gamma$ daily for 3 days into lepromatous lesions induced local induration, T-cell and monocyte infiltration, keratinocyte proliferation and the appearance of HLA-DR (class II or Ia) antigen on the keratinocytes.

In this paper we report that the administration of rIFN- $\gamma$ was non-toxic, induced delayed type hypersensitivity at the site of in jection, decreased the acid-fast bacilli in the skin lesions of patients and that the leprosin A skin test continued to be negative following treatment with rIFN- $\gamma$.

\section{Materials and methods}

Twenty-six leprosy patients (7 female and 19 male, aged 8-70) were studied. They were registered at the infectious diseases section of the Kenyatta National Hospital, Nairobi, and Alupe Leprosy Hospital, Busia, Kenya. All patients underwent a thorough clinical examination, a total and differential blood count, liver function tests, urine and stool examination. The clinical diagnosis of leprosy and the position of the patients on the Ridley-Jopling scale ${ }^{11}$ were confirmed by skin biopsies which were examined by S Lucas and N M Samuel. The majority of the patients were being treated with dapsone, clofazamine and rif ampicin. None of them were being treated with steroids or thalidomide for immunological reactions.

\section{LEPROSIN A SKIN TEST}

Patients were skin-tested with leprosin A, a filtered ultrasonicate of armadillo-derived M. leprae. ${ }^{12}$ The concentration for skin testing was $10 \mu \mathrm{g}$ protein $/ \mathrm{ml}$. Prior to treatment with rIFN- $\gamma$ and 2 days following the last injections, leprosin A $1.0 \mu \mathrm{g}(0.1 \mathrm{ml})$ was injected intradermally into the volar surfaces of the forearms using a $1 \mathrm{ml}$ disposable syringe, fitted with a No. 26 intradermal needle (Becton Dickinson \& Co. Ireland). Skin tests were considered positive if the induration at $48 \mathrm{hr}$ was $5 \mathrm{~mm}$ or more in diameter.

\section{ADMINISTRATION OF rIFN- $\gamma$}

The lyophilized recombinant interferon $\left(2 \times 10^{7}\right.$ units per $\left.\mathrm{mg}\right)$ (Boehringer Ingelheim) was freshly reconstituted in sterile distilled water prior to administration. It was injected in $0.1 \mathrm{ml}$ volumes using $1 \mathrm{ml}$ disposal syringe fitted with a No. 26 intradermal needle. The patients were divided into 3 groups: Group A; 5 lepromatous leprosy patients (LL) were given $10 \mu$ g dose daily for 3 days; Group B; 6 lepromatous leprosy patients were given $20 \mu \mathrm{g}$ dose daily for 3 days; and Group C; 12 LL, 2 B T and 1 indeterminate patient were given $20 \mu \mathrm{g}$ dose daily for 5 days. 
SITE OF ADMINISTRATION OF rIFN- $\gamma$

The injections were administered into dermal leprous lesions over the arms, back or gluteal regions. Each injection site was examined daily for 3 or 4 days and the extent of erythema and induration was recorded. Clinical examination of the patients included special reference to peripheral nerves and the appearance of cutaneous nodules, as it has been reported that leprosy patients treated with 'immunotherapy' are prone to develop immunologically mediated reactions. ${ }^{13}$

\section{BIOPSIES}

Skin biopsies were taken with a 5-mm punch (Downs, UK) from a skin lesion, selected for the IFN- $\gamma$ treatment, on the arm, back or gluteal region. Radial cutaneous nerve biopsies were taken under local anaesthetic ( $1 \%$ xylocaine and adrenaline). Following the treatment with rIFN- $\gamma$ the skin biopsies were repeated adjacent to the original biopsy sites along with the nerve biopsies from the opposite radial cutaneous nerves. These biopsies were taken $48 \mathrm{hr}$ after the final injection of rIFN- $\gamma$. Tissue specimens were placed on paper and divided with a scalpel blade. One portion was fixed in FMA $^{14}$ and later transferred to $70 \%$ alcohol prior to routine processing and staining with haematoxylin and eosin by the Wade-Fite method for acid-fast bacilli. ${ }^{15}$ The other portion of the tissue was snap frozen in liquid nitrogen and transferred to a Cryotube (Nunc, Denmark) and stored in liquid nitrogen. All tissue and serum samples were transported in liquid nitrogen to London. Snap frozen tissues were processed as previously described for immunocytochemical analysis. ${ }^{16}$ Briefly, sections were fixed in acetone at room temperature for $10 \mathrm{~min}$, air-dried for $2 \mathrm{~min}$, washed in phosphate buffered saline (PBS) and incubated sequentially with the following reagents: mouse hybridoma monoclonal antibody, peroxidase conjugated rabbit anti-mouse immunoglobulin, peroxidase conjugated swine anti-rabbit immunoglobulin. The reaction product was developed by incubating in $0 \cdot 1 \%$ diaminobenzidine and $0.3 \%$ hydrogen peroxide in PBS. Sections were counterstained with haematoxylin for $1 \mathrm{~min}$.

\section{Monoclonal antibodies}

Antibody titres used in this study were determined by multiple dilutions and staining of several specimens. Primary mouse hybridoma monoclonal antibodies reacting with human antigens were used as follows:

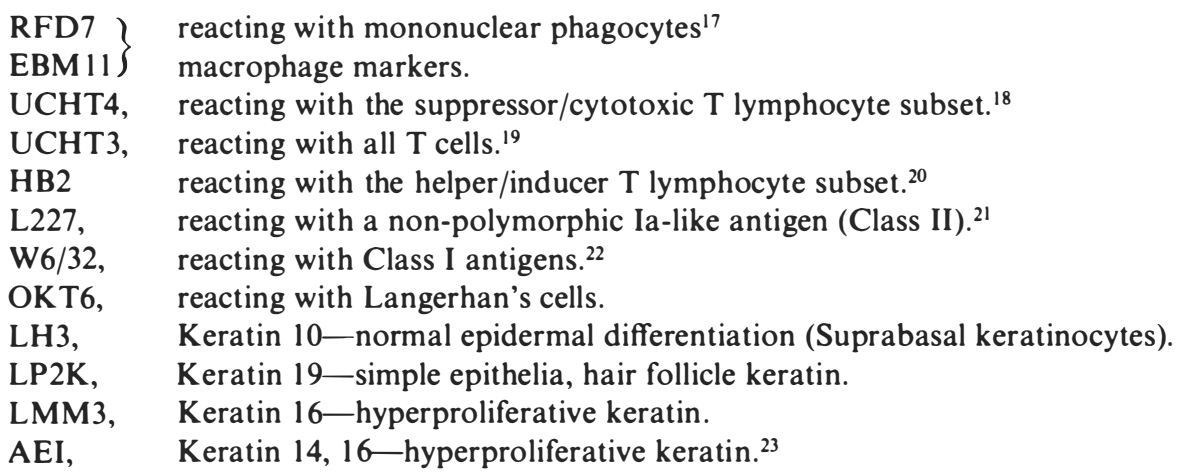




\section{Results}

\section{CLINICAL CHANGES}

Recombinant gamma interf eron was well tolerated by patients except 1 LL patient who developed erythema nodosum leprosum 4 days following the last injection. He was treated with steroids and examination of the peripheral nerves showed no signs of neuritis.

\section{SKIN TESTING}

The leprosin A skin test was negative in all subjects prior to and following the IFN- $\gamma$ treatment.

\section{MACROSCOPIC APPEARANCE OF IFN- $\gamma$ INJECTION SITES}

The mean diameter of induration at the site of injection of rIFN- $\gamma$ was recorded at $24,48,72 \mathrm{hr}$ after the first intradermal injection. It was difficult to measure and record erythema. Induration was apparent between 6 and $12 \mathrm{hr}$ (data not shown), obvious by $24 \mathrm{hr}$ and reached a peak at $48 \mathrm{hr}$. Although declining, a significant degree of induration was still present at $72 \mathrm{hr}$ (Table 1). In 1 patient (C2) the induration continued to persist even after $96 \mathrm{hr}$ and the size of the reaction was $30 \mathrm{~mm}$. Another newly diagnosed active 8-year-old LL patient (C3) had no induration at the first 3 injection sites of $20 \mu \mathrm{g}$ dose of rIFN- $\gamma$. Induration was, however, apparent after $24 \mathrm{hr}$ at the 4th injection site and the course of the reaction was similar to that recorded in other patients. The induration recorded in borderline tuberculoid and indeterminate patients was less marked than in lepromatous leprosy patients.

Table 1. Mean diameter $(\mathrm{mm})$ of the induration induced by rIFN $-\gamma$ after 24,48 and $72 \mathrm{hr}$ in 3 groups of leprosy patients (standard deviations in parentheses).

\begin{tabular}{ccccc}
\hline Group & $24 \mathrm{hr}$ & $48 \mathrm{hr}$ & $72 \mathrm{hr}$ \\
\hline A & $20(8 \cdot 3)$ & $21(8 \cdot 4)$ & $18(8 \cdot 8)$ \\
B & $15(4 \cdot 5)$ & $15(4 \cdot 4)$ & $12(4 \cdot 9)$ \\
C & $11(6 \cdot 2)$ & $13(6 \cdot 6)$ & $11(6 \cdot 6)$ \\
\hline
\end{tabular}

\section{HISTOPATHOLOGY}

Skin biopsies from 23 of the 26 patients were taken both before and after administration of rIFN- $\gamma$. One patient was not biopsied before rIFN- $\gamma$ therapy, one was not biopsied subsequent to therapy and no biopsies were obtained from a further patient. The diagnosis was lepromatous leprosy in 23 patients, borderline tuberculoid in 1, and histologically indeterminate in 1 (see Table 2).

Of the lepromatous cases, 5 had active lesions with large granuloma fractions; the others, who had received more therapy, had regressing lesions consisting mainly of smaller perivascular collections of foamy macrophages and some lymphocytes (Figure 1). These treated cases had acidfast bacilli in small numbers; some had merely granular acid-fast debris or no acid-fast staining material at all (Table 2). No erythema nodosum leprosum reactions or dermal oedema were seen in the pre-rIFN- $\gamma$ biopsies.

Following the rIFN- $\gamma$ inoculation, all but 2 cases showed marked histological changes: 

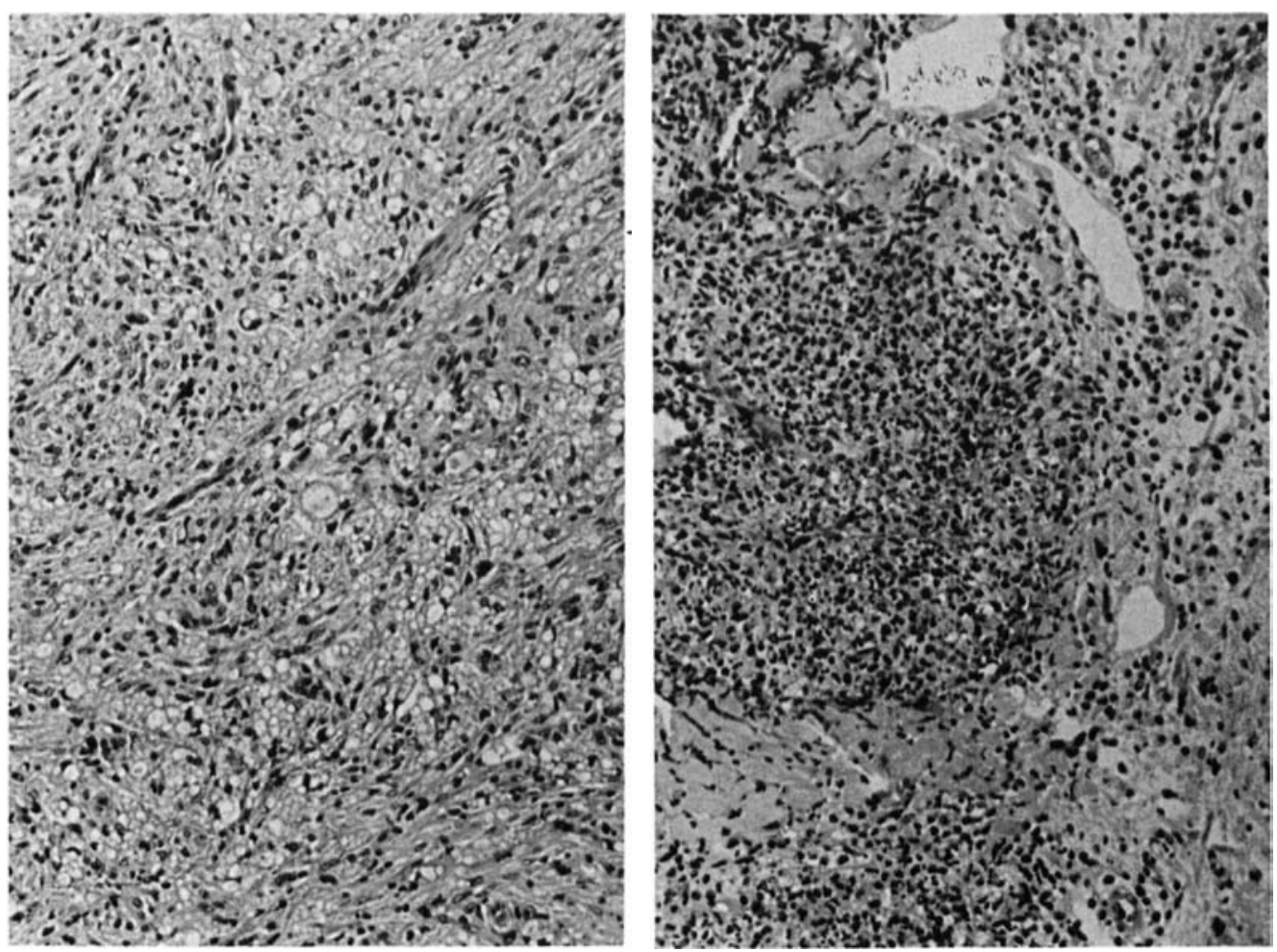

Figure 1. Pre-rIFN- $\gamma$ skin biopsy from patient no. 2 in group A: lepromatous leprosy (LL) with foamy macrophages and globi. Haematoxylin \& eosin $\times 250$.

Figure 2. Post-rIFN- $\gamma$ skin biopsy - same patient as Figure 1: marked influx of inflammatory cells around vessels, mainly lymphocytes but also some eosinophils. Haematoxylin $\&$ eosin $\times 250$.

1 An increase in mononuclear cell infiltrate consisting of macrophages and lymphocytes and extending to the deep dermis. The cellular infiltrate was perivascular, particularly around the superficial and mid-dermal vessels. The mean granuloma fraction of 21 patients prior to rIFN- $\gamma$ was $14 \cdot 29 \%$ (SD 9.29\%) and after rIFN- $\gamma$ was $21.43 \%$ (SD $11 \cdot 14 \%$ ). Thus the granuloma fractions showed a mean increase of $50 \%$ and this increase was significant $(P<0.05)$ (Figure 2).

2 Hypertrophy of the endothelial cells of the dermal vessels.

3 Dermal oedema.

4 Eight of the post-rIFN- $\gamma$ biopsies from lepromatous leprosy patients showed epithelioid cell transformation, i.e. a change in the cytoplasmic and nuclear morphology of the macrophage infiltrate into epithelioid cells (Figure 3). In none, however, was there formation of tuberculoid granulomas. The tendency for epithelioid cell transformation was most marked in group $\mathrm{C}$ patients who were given $20 \mu \mathrm{g}$ rIFN- $\gamma$ daily for 5 days. One borderline tuberculoid leprosy case showed an increased number of epithelioid cells in the dermal infiltrate after injection of rIFN- $\gamma$.

5 Twelve of the post-rINF- $\gamma$ biopsies showed marked dermal infiltrates with both neutrophil polymorphs and eosinophils. An additional 2 had polymorphs and 2 had eosinophils only. Vasculitis, i.e. inflammatory infiltrate through a vessel wall, was seen in 4 cases and, in one of them, the picture was of a necrotizing vasculitis with fibrin exudates (Figure 4 ). These 4 patients had all received the higher $(20 \mu \mathrm{g})$ dose.

6 In the H\&E sections, the epidermis in pre- and post-rIFN- $\gamma$ inoculation biopsies was similar 
Table 2. Summary of microscopic findings

\begin{tabular}{|c|c|c|c|c|c|c|c|c|c|c|c|}
\hline \multirow[b]{2}{*}{ No. } & \multirow{2}{*}{$\begin{array}{l}\text { Age } \\
\text { and } \\
\text { sex }\end{array}$} & \multirow{2}{*}{$\begin{array}{c}\text { Histological } \\
\text { diagnosis }\end{array}$} & \multirow[b]{2}{*}{ Biopsy } & \multirow{2}{*}{$\begin{array}{c}\text { Granuloma } \\
\text { fraction } \\
\%\end{array}$} & \multirow{2}{*}{$\begin{array}{c}\text { Mononuclear } \\
\text { cellular } \\
\text { infiltrate }\end{array}$} & \multirow{2}{*}{$\begin{array}{l}\text { Polymorph } \\
\text { infiltrate }\end{array}$} & \multirow{2}{*}{$\begin{array}{l}\text { Eosinophil } \\
\text { infiltrate }\end{array}$} & \multirow[b]{2}{*}{ Vasculitis } & \multirow{2}{*}{$\begin{array}{c}\text { Epithelioid } \\
\text { cell- } \\
\text { transformation }\end{array}$} & \multicolumn{2}{|c|}{ Change in bacillary load } \\
\hline & & & & & & & & & & BI & AF debris \\
\hline \multicolumn{12}{|c|}{ Group A: rIFN $-\gamma 10 \mu \mathrm{g}$ dose for 3 days } \\
\hline 1 & $45 \mathrm{M}$ & LL & $\begin{array}{l}\text { Pre } \\
\text { Post }\end{array}$ & $\begin{array}{c}10 \\
\text { ND }\end{array}$ & & & & & & $\stackrel{1}{N D}$ & $\stackrel{+}{\text { ND }}$ \\
\hline 2 & $42 \mathrm{M}$ & LL & $\begin{array}{l}\text { Pre } \\
\text { Post }\end{array}$ & $\begin{array}{l}50 \\
35\end{array}$ & + & + & + & - & + & $\begin{array}{l}2 \cdot 5 \\
2\end{array}$ & $\begin{array}{l}0 \\
0\end{array}$ \\
\hline 3 & $50 \mathrm{M}$ & LL & $\begin{array}{l}\text { Pre } \\
\text { Post }\end{array}$ & $\begin{array}{l}15 \\
15\end{array}$ & + & - & - & - & - & $\begin{array}{l}2 \\
2\end{array}$ & $\begin{array}{l}+ \\
+\end{array}$ \\
\hline 4 & $52 \mathrm{M}$ & LL & $\begin{array}{l}\text { Pre } \\
\text { Post }\end{array}$ & $\begin{array}{l}10 \\
25\end{array}$ & + & - & - & - & - & $\begin{array}{l}0 \\
0\end{array}$ & $\begin{array}{l}+ \\
+\end{array}$ \\
\hline 5 & $30 \mathrm{~F}$ & LL & $\begin{array}{l}\text { Pre } \\
\text { Post }\end{array}$ & $\begin{array}{l}25 \\
40\end{array}$ & + & - & - & - & - & $\begin{array}{l}5 \\
5\end{array}$ & $\begin{array}{l}+ \\
+\end{array}$ \\
\hline \multicolumn{12}{|c|}{ Group B: rIFN- $\gamma 20 \mu \mathrm{g}$ dose for 3 days } \\
\hline 1 & $40 \mathrm{~F}$ & LL & $\begin{array}{l}\text { Pre } \\
\text { Post }\end{array}$ & $\begin{array}{r}<10 \\
20\end{array}$ & + & - & + & - & - & $\begin{array}{l}1 \\
2\end{array}$ & $\begin{array}{l}0 \\
0\end{array}$ \\
\hline 2 & $39 \mathrm{M}$ & LL & $\begin{array}{l}\text { Pre } \\
\text { Post }\end{array}$ & $\begin{array}{l}25 \\
25\end{array}$ & + & + & + & - & - & $\begin{array}{l}2 \\
1\end{array}$ & $\begin{array}{l}+ \\
0\end{array}$ \\
\hline 3 & $53 \mathrm{M}$ & LL & $\begin{array}{l}\text { Pre } \\
\text { Post }\end{array}$ & $\begin{array}{l}10 \\
25\end{array}$ & + & + & - & - & + & $\begin{array}{l}2 \cdot 5 \\
2\end{array}$ & $\begin{array}{l}+ \\
+\end{array}$ \\
\hline 4 & $50 \mathrm{M}$ & LL & $\begin{array}{l}\text { Pre } \\
\text { Post }\end{array}$ & $\begin{array}{l}10 \\
50\end{array}$ & + & + & + & - & - & $\begin{array}{l}2 \\
3\end{array}$ & $\begin{array}{l}+ \\
+\end{array}$ \\
\hline 5 & $28 \mathrm{M}$ & LL & $\begin{array}{l}\text { Pre } \\
\text { Post }\end{array}$ & $\begin{array}{l}10 \\
40\end{array}$ & + & + & + & + & - & $\begin{array}{l}0 \\
0\end{array}$ & $\begin{array}{l}+ \\
+\end{array}$ \\
\hline 6 & $42 \mathrm{~F}$ & LL & $\begin{array}{l}\text { Pre } \\
\text { Post }\end{array}$ & $\begin{array}{l}\text { ND } \\
80\end{array}$ & + & - & - & - & - & $\begin{array}{l}\text { ND } \\
5\end{array}$ & $\begin{array}{l}\text { ND } \\
+\end{array}$ \\
\hline
\end{tabular}


Table 2. (continued)

\begin{tabular}{|c|c|c|c|c|c|c|c|c|c|c|c|}
\hline \multirow[b]{2}{*}{ No. } & \multirow{2}{*}{$\begin{array}{l}\text { Age } \\
\text { and } \\
\text { sex }\end{array}$} & \multirow{2}{*}{$\begin{array}{c}\text { Histological } \\
\text { diagnosis }\end{array}$} & \multirow[b]{2}{*}{ Biopsy } & \multirow{2}{*}{$\begin{array}{c}\text { Granuloma } \\
\text { fraction } \\
\%\end{array}$} & \multirow{2}{*}{$\begin{array}{l}\text { Mononuclear } \\
\text { cellular } \\
\text { infiltrate }\end{array}$} & \multirow{2}{*}{$\begin{array}{l}\text { Polymorph } \\
\text { infiltrate }\end{array}$} & \multirow{2}{*}{$\begin{array}{l}\text { Eosinophil } \\
\text { infiltrate }\end{array}$} & \multirow[b]{2}{*}{ Vasculitis } & \multirow{2}{*}{$\begin{array}{l}\text { Epithelioid } \\
\text { cell- } \\
\text { transformation }\end{array}$} & \multicolumn{2}{|c|}{ Change in bacillary load* } \\
\hline & & & & & & & & & & BI & AF debris \\
\hline \multicolumn{12}{|c|}{ Group C: rIFN- $\gamma 20 \mu \mathrm{g}$ dose for 5 days } \\
\hline \multirow{2}{*}{\multicolumn{2}{|c|}{$142 \mathrm{M}$}} & LL & Pre & 10 & & & & & & 0 & 0 \\
\hline & & & Post & 20 & + & + & - & - & - & 0 & 0 \\
\hline \multirow[t]{2}{*}{2} & $38 \mathrm{M}$ & LL & Pre & 70 & & & & & & 5 & 0 \\
\hline & & & Post & 15 & + & - & - & - & + & $3 \cdot 5$ & 0 \\
\hline \multirow[t]{2}{*}{3} & $8 \mathrm{M}$ & LL & Pre & 20 & & & & & & 5 & 0 \\
\hline & & & Post & 15 & + & - & - & - & + & $4 \cdot 5$ & 0 \\
\hline \multirow[t]{2}{*}{4} & $45 \mathrm{M}$ & LL & Pre & 10 & & & & & & 0 & + \\
\hline & & & Post & 10 & + & - & - & - & - & 0 & 0 \\
\hline \multirow[t]{2}{*}{5} & $70 \mathrm{~F}$ & BT & Pre & 10 & & & & & & 0 & 0 \\
\hline & & & Post & 10 & + & - & + & - & + & 0 & 0 \\
\hline \multirow[t]{2}{*}{6} & $62 \mathrm{M}$ & LL & Pre & $<10$ & & & & & & 0 & + \\
\hline & & & Post & 15 & + & + & + & - & + & 0 & 0 \\
\hline \multirow[t]{2}{*}{7} & $? \mathrm{~F}$ & LL & Pre & 10 & & & & & & 0 & + \\
\hline & & & Post & 15 & + & + & + & + & - & 0 & 0 \\
\hline \multirow[t]{2}{*}{8} & $40 \mathrm{M}$ & LL & Pre & 15 & & & & & & ND & ND \\
\hline & & & Post & 25 & + & + & + & + & + & 1 & 0 \\
\hline \multirow[t]{2}{*}{9} & $40 \mathrm{M}$ & LL & Pre & 10 & & & & & & 2 & 0 \\
\hline & & & Post & 15 & + & + & + & - & - & 0 & + \\
\hline \multirow[t]{2}{*}{10} & $50 \mathrm{M}$ & LL & Pre & $<10$ & & & & & & 0 & 0 \\
\hline & & & Post & 10 & + & + & + & + & + & 0 & 0 \\
\hline \multirow[t]{2}{*}{11} & $24 \mathrm{M}$ & LL & Pre & 80 & & & & & & 5 & + \\
\hline & & & Post & 10 & + & - & - & - & - & $4 \cdot 5$ & + \\
\hline \multirow[t]{2}{*}{12} & $45 \mathrm{M}$ & IND & Pre & 10 & & & & & & 0 & 0 \\
\hline & & & Post & $<10$ & + & + & + & - & - & 0 & 0 \\
\hline 13 & $10 \mathrm{M}$ & BT & & ND & & & & & & & \\
\hline \multirow[t]{2}{*}{14} & $26 \mathrm{~F}$ & LL & Pre & $<10$ & & & & & & 0 & + \\
\hline & & & Post & 20 & + & + & + & - & + & 0 & 0 \\
\hline \multirow[t]{2}{*}{15} & $40 \mathrm{~F}$ & LL & Pre & 10 & & & & & & 2 & 0 \\
\hline & & & Post & 10 & + & + & + & - & - & 2 & 0 \\
\hline
\end{tabular}

* AF Debris, granular acid-fast debris inside macrophages not countable as fragmented or solid rods. $\mathrm{BI}$, logarithmic bacterial index of solid or fragmented bacilli in the granuloma. ${ }^{31}$ 

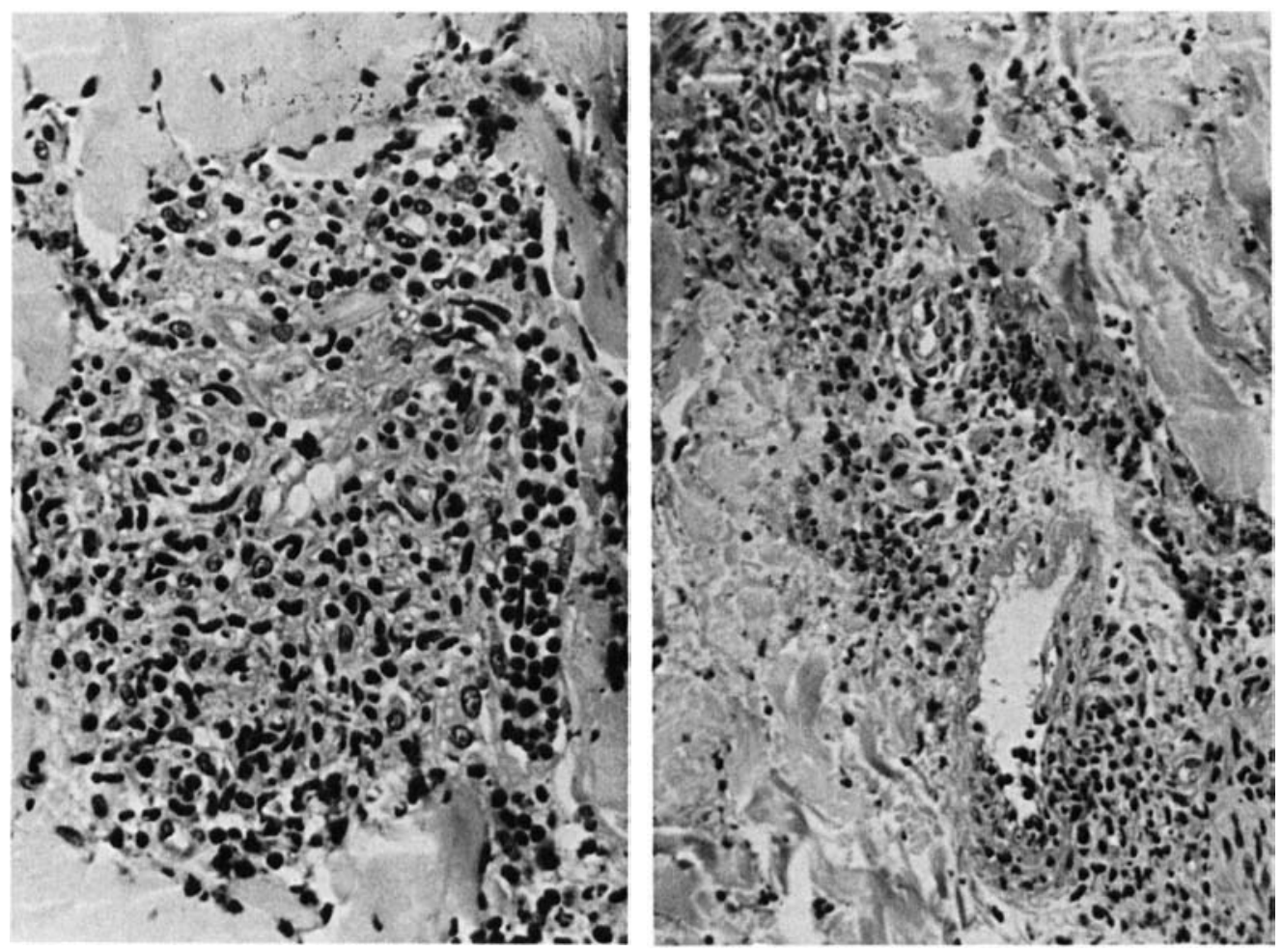

Figure 3. Post-rIFN- $\gamma$ skin biopsy from patient no. 3 in group B: lymphocytes and macrophages around vessel. Many of the macrophages are spindly and epithelioid in morphology. Haematoxylin \& eosin $\times 500$.

Figure 4. Post-rIFN- $\gamma$ skin biopsy from patient no. 8 in group C: and segmental necrosis of the vessel wall (vasculitis). Haematoxylin \& eosin $\times 400$.

apart from some spongiotic oedema and a focal mild increase in intraepithelial lymphocytes in some post-rIFN- $\gamma$ biopsies. Only one of the latter had mitotic evidence of epidermal proliferation.

7 Seven of the $12 \mathrm{LL}$ patients with recordable bacillary indices showed a marked decrease in the numbers of acid-fast bacilli in the skin lesions following inoculation of rIFN- $\gamma$. There was a mean drop of $\log 0.9$ (i.e. 9 -fold) in the bacterial index. In 2 there was an increase in the index after rIFN- $\gamma$ (from $1+$ to $2+$; and $2+$ to $3+$ ) respectively. The change in $\mathrm{Bl}$ was similar in the 3 groups. In 3 patients no difference in bacterial indices were observed following rIFN- $\gamma$. Acid-fast debris only was seen in 7 patients before the injection of rIFN- $\gamma$ : this disappeared after treatment in 4 of the patients. The nerve biopsies taken at the same time as the skin biopsies showed no change in the cellular infiltrate and no change in the bacterial indices following rIFN- $\gamma$.

\section{IMMUNOCYTOCHEMISTRY}

Before rIFN- $\gamma$, skin lesions of LL patients contained very few cells reacting with UCHT3 (equivalent to pan T): most of these reacted with UCHT4 (equivalent to $\mathrm{T}_{8}$ ). The L227 (anti-HLAclass II) antibody showed faint and diffuse staining of macrophages in lesions of LL, BT and indeterminate patients. Epidermal keratinocytes were class II negative. Langerhans (OKT6+) cells were seen in the epidermis and in the dermal granulomas of LL and BT patients.

Following rIFN- $\gamma$, cells positive with pan T-cell marker increased and both T-cell phenotypes, $T_{8}$ and $T_{4}$, were roughly equal in numbers. The number of macrophages also increased but there 


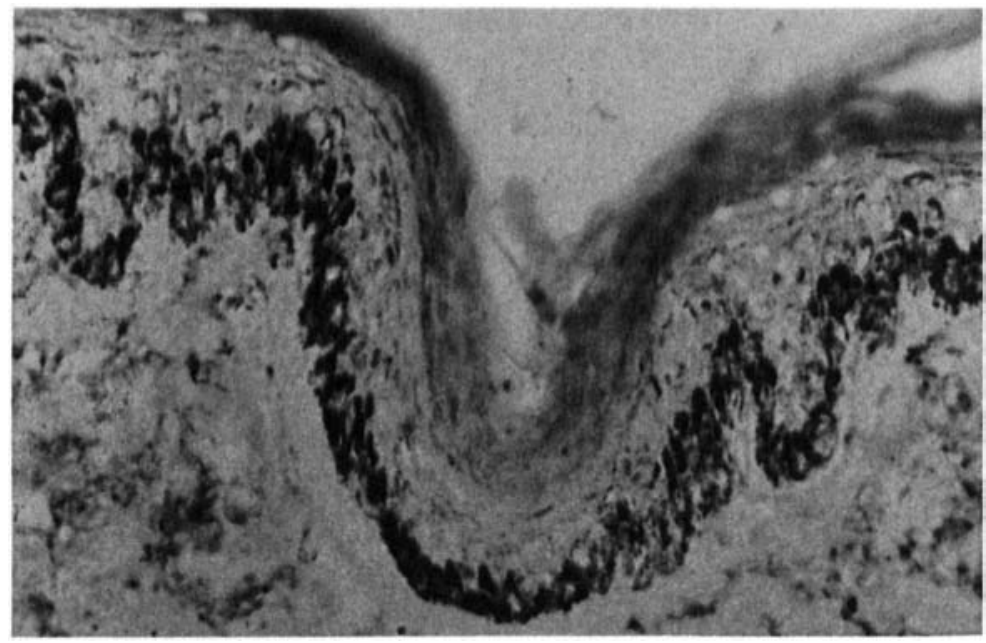

Figure 5. Pre-rIFN- $\gamma$ skin biopsy from patient no. 2 in group C: Immunoperoxidase stain for L227 (HLA-class II antigens). No staining of epidermal keratinocytes (the basal cells are pigmented by melanin). $\times 400$.

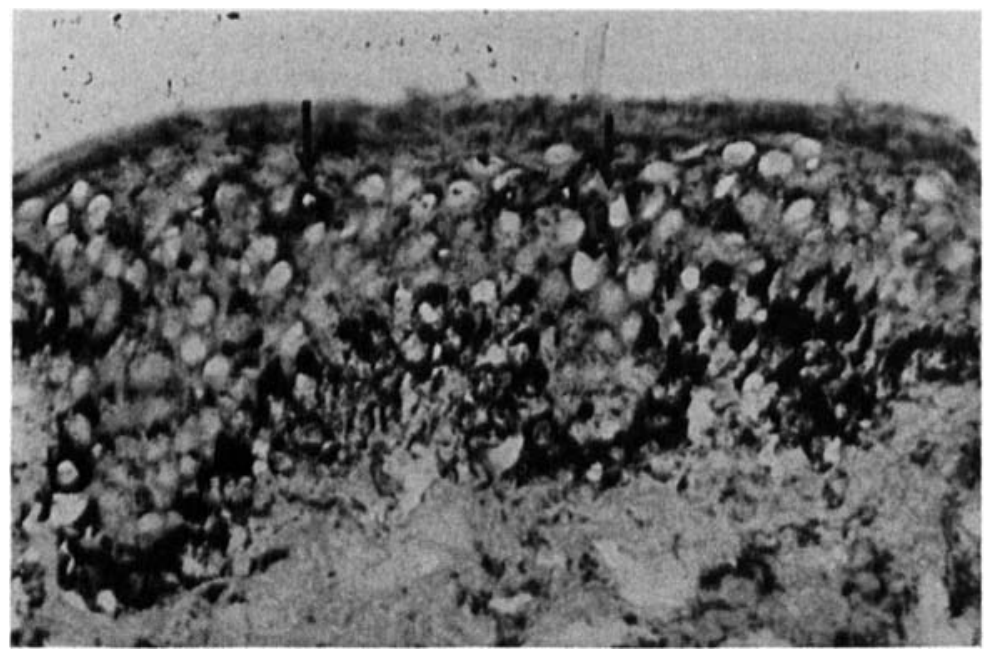

Figure 6. Post-rIFN- $\gamma$ skin biopsy-same patient at Figure 5: Immunoperoxidase stain for L227 (HLA-class II antigens). Postive staining of epidermal keratinocytes (arrows). $\times 400$.

were no changes in the numbers of Langerhans (OKT6+) cells. Cells in the dermis and the vascular endothelium were strongly HLA-class II positive. Following rIFN- $\gamma$ inoculation the epidermal keratinocytes also became HLA-class II positive but the hyperproliferative markers $A_{1}$ and LMM3 remained negative (Figures 5 and 6).

\section{Discussion}

Intradermal administration of recombinant gamma interferon resulted in several immunological changes in the lesions of lepromatous leprosy patients. The most striking change was the induction 
of delayed type hypersensitivity (DTH) in all patients irrespective of the type of the disease, dose or the numbers of rIFN- $\gamma$ injections. This resulted in oedema, a massive influx of mononuclear cells and eosinophils and an increase in the granuloma fraction. The smaller extent of induration observed in patients with BT and indeterminate disease suggests that the gross pre-existing dermal infiltration in LL disease predisposes to the induction of DTH by INF- $\gamma$. The bacterial index decreased in the majority of patients by an average of $-\log 0 \cdot 9$. The epithelioid cell transformation and the appearance of HLA-class II antigens on the epidermal keratinocytes was remarkable and confirm the observations of Nathan et al. ${ }^{10}$

To eliminate interlesional variation, the biopsies were taken very close to one another. In 2 patients the sites were dissimilar making it difficult to compare the granuloma fractions. The induction of DTH and the epithelioid cell transformation indicate a shift in the immune spectrum towards the tuberculoid pole. This may be a direct effect of IFN- $\gamma$ or it may result from the induction of other lymphokines. The epithelioid cell transformation was seen most in the group receiving the highest dose of IFN- $\gamma$ (group C).

The clearance of acid-fast bacteria in multibacillary leprosy is slow and prolonged. Studies in the past had shown that high ${ }^{24}$ and low doses ${ }^{13}$ of mixed vaccines $(B C G+M$. leprae) resulted in the recruitment of mononuclear cells with the elimination of bacteria from the leprous skin lesions. In addition, reactions to skin test reagents prepared from $M$. leprae (e.g. leprosin A) became positive following the immunotherapy with mixed vaccines in some multibacillary patients, suggesting that immunotherapy had a systemic effect. This is in contrast to the observation of the present study that leprosin A skin tests continued to be negative in all patients.

The observation that no cellular changes occurred in peripheral nerves following rIFN- $\gamma$, indicates that the dosage used in this study was inadequate to induce a systemic effect. However, the rIFN- $\gamma$ was superior to the mixed vaccines with respect to the rapidity of the elimination of acid-fast bacteria and the induction of other immunological changes.

We were concerned that the increased degradation of $M$. leprae associated with DTH might lead to immunological reactional states. Only $1 \mathrm{LL}$ patient developed erythema nodosum leprosum with no neural damage. This was the same patient with a persistent induration up to $96 \mathrm{hr}$ following the injection of rIFN- $\gamma$. All the patients in the study were receiving chemotherapy and we do not therefore have any evidence that the reactional state in the single patient was due to rIFN- $\gamma$. It will be of considerable importance to consider the possibility of systemic reaction when designing further studies, especially if IFN- $\gamma$ is administered parenterally.

In 14 of the post-rIFN- $\gamma$ biopsies, eosinophils and degranulated eosinophils formed a large part of the infiltrate. With one exception these were seen in patients who received the higher $(20 \mu \mathrm{g})$ dose. The significance of their presence in DTH was unclear. Nevertheless, eosinophils are implicated as effector cells in some disease states, ${ }^{25}$ including leprosy, and produce pharmacological mediators such as eosinophil peroxidase with known microbicidal activity. ${ }^{26}$ Eosinophils may therefore exert a bactericidal activity additional to that of the activated macrophages.

Immunocytochemical analysis of post-rIFN- $\gamma$ biopsies revealed that there was an increase in pan $T$ cells and that the $T_{4}$ and $T_{8}$ cells became roughly equal in number. This is another striking observation in LL patients following rIFN- $\gamma$. In vitro assays had shown that rIFN- $\gamma$ induced HLAclass II expression on vascular endothelial cells, ${ }^{27}$ macrophages, ${ }^{28}$ and Schwann cell cultures infected with $M$. leprae. ${ }^{29}$ Similarly invivo administration of rIFN- $\gamma$ induced HLA-class II positivity on epidermal keratinocytes. The battery of monoclonal antibody markers for keratinocytes used in this study did not, however, show evidence of the altered differentiation usually found during the hyperproliferation of keratinocytes. This observation is in contrast to that of Nathan et al. ${ }^{10}$ The reason for this discrepancy is not known although rIFN- $\gamma$ has been shown to inhibit cell growth. ${ }^{30}$

In conclusion, we have shown that rIFN- $\gamma$ administration in small doses in LL, BT and indeterminate patients induced DTH reactions. The monocyte-macrophage activation with rapid bacterial clearance in lepromatous leprosy patients and the increase in pan $T$ and $T_{4}$ cells indicated a shift in the immune spectrum towards the tuberculoid pole. Further studies with larger doses of 
rIFN- $\gamma$ and for more prolonged periods in lepromatous leprosy are required in order to establish whether this agent will be a useful adjunct to chemotherapy in leprosy.

\section{Acknowledgments}

We wish to thank Mr Ngala, Dr Khan, Sister Ritoch, Mr Khalid, Mrs C Moore, Mr A Rhodes, Mr H A Navsavia and Miss J Gibson for their technical assistance and Mrs Joyce Murphy for typing the manuscript. We are also grateful to the staff of the infectious diseases hospital, Kenyatta National Hospital and Alupe Leprosy Hospital, and to Dr Babu Swai and Mr E Edwards for making arrangements for the transport of specimens to London. We thank Dr J Colston for the gift of leprosin A skin test reagent and Drs T T Sun and I Gardner for the gifts of the AE-I and LMM3 monoclonal antibodies.

This study was supported by a grant from Boehringer Ingelheim. We are indebted to Dr N Snell for his participation in the planning of this study.

\section{References}

${ }^{1}$ Bullock WE, Fasal P. Studies of immune mechanisms in leprosy. J Immunol, 1971; 106: 888-99.

${ }^{2}$ Godal T. Immunological aspects of leprosy_present status. Prog Allergy, 1978; 25: 211-42.

3 Van Voorhis WCG, Kaplan G, Sarno EN, Horwitz MA, Steinman RM, Levis WR, Nogueira N, Hair LA, Gattass CR, Arrick BA, Cohn ZA. The cutaneous infiltrates of leprosy. Cellular characteristics and the predominant T cell phenotypes. N Eng J Med, 1982; 307: 1593-7.

${ }^{4}$ Nogueira N, Kaplan G, Levy E, Sarno EN, Kushner P, Granelli-Piperno A, Viera L, Colomer-Gould V, Levis W, Steinman RR, Yip YK, Cohn ZA. Defective interferon production in leprosy. Reversal with antigen and interleukin-2. Jexp Med, 1983; 158: 2165-70.

5 Horwitz MA, Levis WR, Cohn ZA. Defective production of monocyte-activity cytokines in lepromatous leprosy. J exp Med, 1984; 158: 666-78.

${ }^{6}$ Kasahara J, Hooks JJ, Dougherty SF, Oppenheim JJ. IL2 mediated immune interferon production by human T cells and T cell subsets. $J$ Immunol, 1983; 30: 1784-9.

7 Nathan CF, Murray HW, Wiebe ME, Rubin BY. Identification of interferon- $\gamma$ as the lymphokine that activates human macrophage oxidative metabolism and antimicrobial activity. Jexp Med, 1983; 158: 670 89.

${ }^{8}$ Nogueira N, Cohn ZA. Trypanosoma cruzi: in vitro induction of macrophage microbicidal activity. J exp Med, 1978; 148: 288-300.

9 Edwards CK, Hedegaard HB, Zlotaik A, Gangadharam PR, Johnston RB Jnr, Pabst MJ. Chronic infection due to $M$ ycobacterium intracellulare in mice: Association with macrophage release of prostaglandin $E_{2}$ and reversal by injection of indomethacin, muramyl dipeptide, and interferon- $\gamma$. J Immunol, 1986; 136: $1820-7$.

10 Nathan CF, Kaplan G, Levis WR, Nusvat A, Witmer MD, Sherwin AS, Job CK, Horowitz CR, Steinman $\mathrm{RM}$, Cohn ZA. Local and systemic effects of intradermal recombinant interferon- in patients with lepromatous leprosy. N Engl J Med, 1986; 313: 6-15.

11 Ridley D, Jopling WH. Classification of leprosy according to immunity: a five group system. Int J Lepr, 1966; 34: 255-73.

12 World Health Organization. Report of the Third IMMLEP Scientific Working Group on Leprosy. Protocol 3/77. WHO Document DR/SWG/IMMLEP (3) p. 20.1977.

${ }_{13}$ Samuel NM, Neupani K, London J, Samuel S. Vaccination of leprosy patients and healthy contacts. Ind J Lepr, 1985; 57: 288-95.

14 Lowy L. Processing of biopsies for leprosy bacilli. J Med Lab Technol, 1956; 13: 558-62.

15 Wade HW. A modification of the fite formaldehyde (fite I) method for staining acid-fast bacilli in paraffin sections. Stain Technol, 1957; 32: 287-92.

16 Gatter KC, Cordell JL, Falini B et al. Monoclonal antibodies in diagnostic pathology: techniques and applications. J Biol Response Mod, 1983; 2: 369-95.

17 Janossy G, Bofill M, Poulter LW, Rawlings E, Burford GD, Navarrette C, Ziegler A, Kelemen E. Separate autogeny of the macrophage-like accessory cell populations in the human foetus. J Immunol, 1986; 136: 4354-61.

18 Beverley PCL. Joint Report of the lst Workshop in human leukocyte differentiation antigens in leucocyte typing, p. 26. Bernard A, Boumsell L, Davsset J, Milstein C, Schlossman S. (eds) Berlin: Springer Verlag, 1984. 
19 Beverley PCL, Callard RE. Distinctive functional characteristics of human ' $T$ ' lymphocytes defined by E rosetting or a monoclonal anti-T cell antibody. Eur J Immunol, 1981; 11: 329-34.

${ }^{20}$ Eisenbarth GS, Barton FH, Schroer JA, Fauci AS. Production of monoclonal antibodies reacting with peripheral blood mononuclear cell surface differentiation antigen. J Immunol, 1980; 124: 1237-44.

${ }^{21}$ Lampson LA, Levy R. Two populations of la-like molecules on a human B cell line. J Immunol, 1980; 125: 293-9.

22 Barnstable CJ, Bodmer WF, Brown G, Galfre G, Milstein C, Williams AF, Ziegler A. Production of monoclonal antibodies to group A erythrocytes, HLA and other human cell surface antigens. New tools for genetic analysis. Cell, 1978; 14: 9-20.

${ }^{23}$ Weiss AR, Guillet GYA, Freedberg MI, Farmer RE, Small AE, Weiss MM, Sun TT. The use of monoclonal antibody to keratin in human epidermal disease: Alterations in immunohistochemical staining pattern. $J$ Invest Dermatol, 1983; 81: 224-30.

${ }^{24}$ Convit J, Arauzazu N, Ulrich M, Pinardi ME, Reyes O, Alvarado J. Immunotherapy with a mixture of Mycohacterium leprae and BCG in different forms of leprosy and in Mitsuda-negative contacts. Int J Lepr, 1982; 50: 415-24.

${ }^{25}$ Samuel NM, Stanford JL, Desikan KV. Microscopic findings of delayed reactions elicited by the skin test reagent Leprosin A derived from M. leprae. Int J Lepr, 1985; 53: 395-403.

${ }^{26}$ Klebanoff JS, Shepard CC. Toxic effect or the peroxidase-hydrogen peroxide-halide antimicrobial system on Mycobacterium leprae. Infect Immun, 1984; 44: 534-6.

27 Pober JS, Gimbrone MA, Cotran RS, Reiss CS, Fiers W, Ault KA. Ia expression by vascular endothelium is induced by activated T cells and by human $\gamma$-interferon. J exp Med, 1983; 157: 1339-53.

${ }^{28}$ Steeg PS, Moore RN, Johnson HH, Oppenheim JJ. Regulation of murine macrophage Ia antigen expression by a lymphokine with immune interferon activity. J exp Med, 1982; 156: 1780-93.

${ }^{29}$ Samuel NM, Jessen KR, Grange JM, Mirsky R. Gamma interferon, but not Mycobacterium leprae, induces major histocompatibility class II (Ia) antigens on cultured rat schwann cells. J Neurocytol 1987; 16: $281-7$.

${ }^{30}$ Evinger M, Rubinstein M, Pestka S. Antiproliferative and antiviral activities of human leucocyte interferon. Arch Biochem Biophys, 1981; 210: 319-29.

${ }^{31}$ Ridley DS. Skin Biopsy in Leprosy. Second edition, Documenta Geigy, 1985.

\section{LEPROSY CONTROL AND FIELD WORK}

\section{Leprosy Control in Nepal}

We have recently received the Annual Report (to July 1986) of the Joint Programme of His Majesty's Government of Nepal and the International Nepal Fellowship/German Leprosy Relief Association in the West, Mid-West and Far West Regions of Nepal. The following is extracted from the introduction:

In 1975, the National Leprosy Control Project was established in the whole country. There was a project formulation. While work in the eastern half of the country was taken up by HMG/N itself, the INF was made responsible for LCP work in the western half of the country.

At the end of its first 5 years, there was an evaluation of the NLCP in the Western and Far Western Regions of Nepal (now Western, Mid-Western and Far Western regions of Nepal) covering $4 \frac{1}{2}$ years. This evaluation led to a change in the case-finding methodology from the population surveys to a concentration on health education and quality care.

Multidrug treatment was introduced in April 1982, following guidelines defined at the 2nd National Workshop on Leprosy Control in November 1981.

After 4 full years of MDT, the eff ect of that treatment can be seen in a reduction of registered prevalence in the areas where it was first introduced.

The project has now been running 11 years.

MDT has been given to $40 \%$ of patients in the field and is available to 25 out of 27 districts. Regularity of attendance in these patients has been exceptionally good. During the past 4 years, 4206 patients have been released from control. Source: Administrative Director, International Nepal Fellowship, The Programme Office, PO Box 5, Pokhava, Nepal 33701. 